\title{
Regina Waterfowl Park Nesting Survey 1962
}

\section{by Richard M. Sanderson, Regina}

In June, 1962, Mr. Fred Bard, Director of the Saskatchewan Museum of Natural History, engaged Bill Fleming and myself to carry out a survey of breeding birds in the marsh habitat of the Regina Waterfowl Park, working from "Tern Island" (see map) east along the Wascana Creek to approximately a mile beyond the Highway No. 1 by-pass. The object of our survey was to record the number and location of breeding species of birds as a record of what species the Waterfowl Park now affords protection to during the nesting season. This survey came about as a result of the Wascana Development Plan. The changes that will take place in the marsh habitat owing to the plan for development will undoubtedly force some species to vacate the area. Thus, some birds that commonly breed here now may in the future become rare as breeding species. Hence the importance of obtaining a record of what we have presently nesting here.

The success of a nesting season depends mainly on weather conditions.
With the aid of the monthly meteorological bulletin published by the Department of Transport, Regina Airport, the fcllowing summary of weather conditions during the nesting season (May-July) was prepared. The May weather was cool during the first half of the month and a little above the normal temperature during the latter half. The average temperature was $50.1^{\circ}$ while the normal is $52.2^{\circ}$. The total precipitation was 1.68 inches, .09 inches above normal. Regina's June weather was mainly wet and cool during the first half and sunny and warm during the last half. The average temperature was $63.2^{\circ}$ compared to a normal of $59.5^{\circ}$. Total preciptation was 3.82 inches, .54 inches above normal. On June 27 a new all-time high wind speed of 95 m.p.h. in gusts was registered. Regina had its ccolest July in 10 years with the temperature averaging $63.1^{\circ}$ compared to a normal of $66.7^{\circ}$. The tctal precipitation was .15 inches below normal. Weather was responsible for little damage in the marsh except that some Yellow-headed

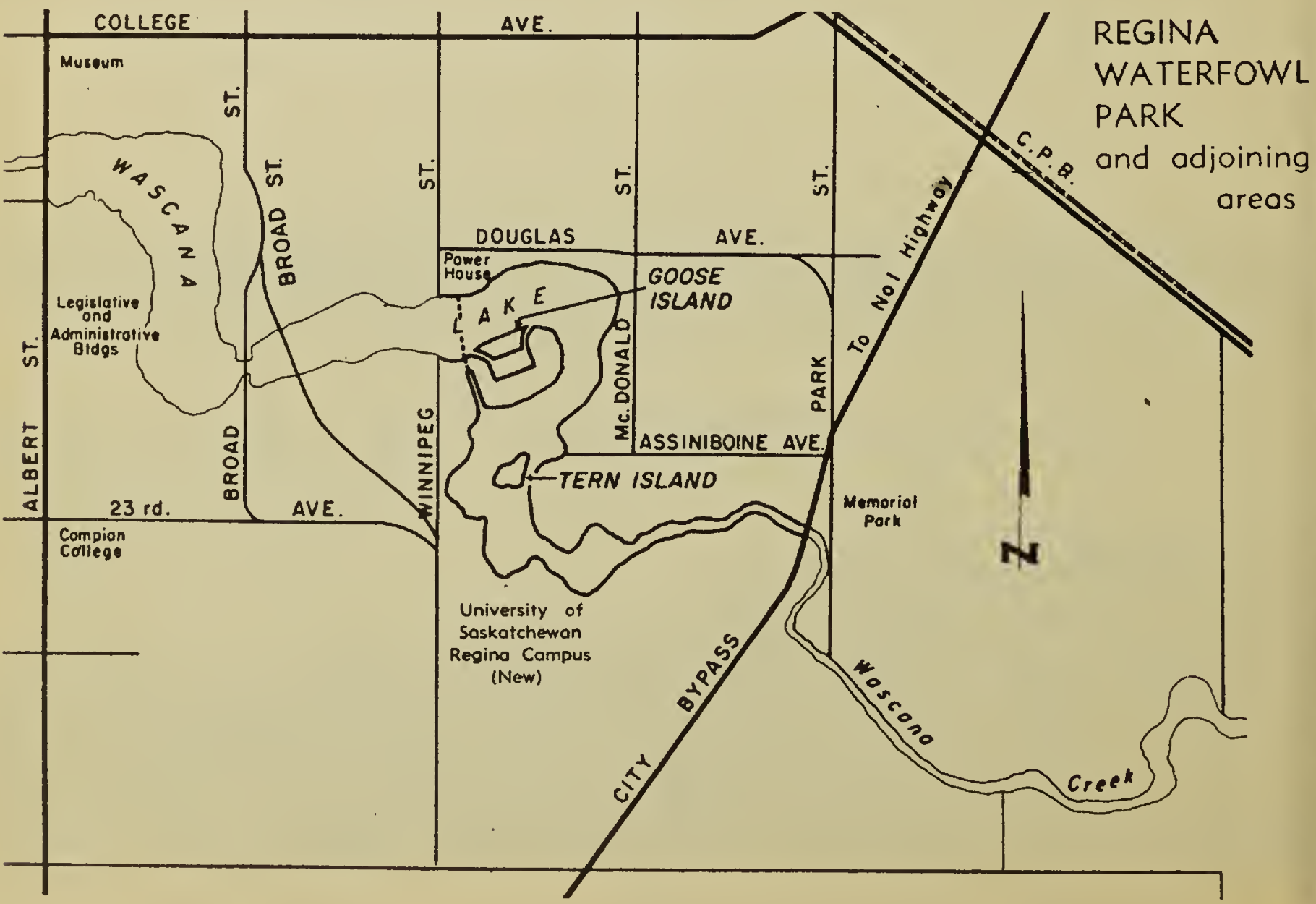




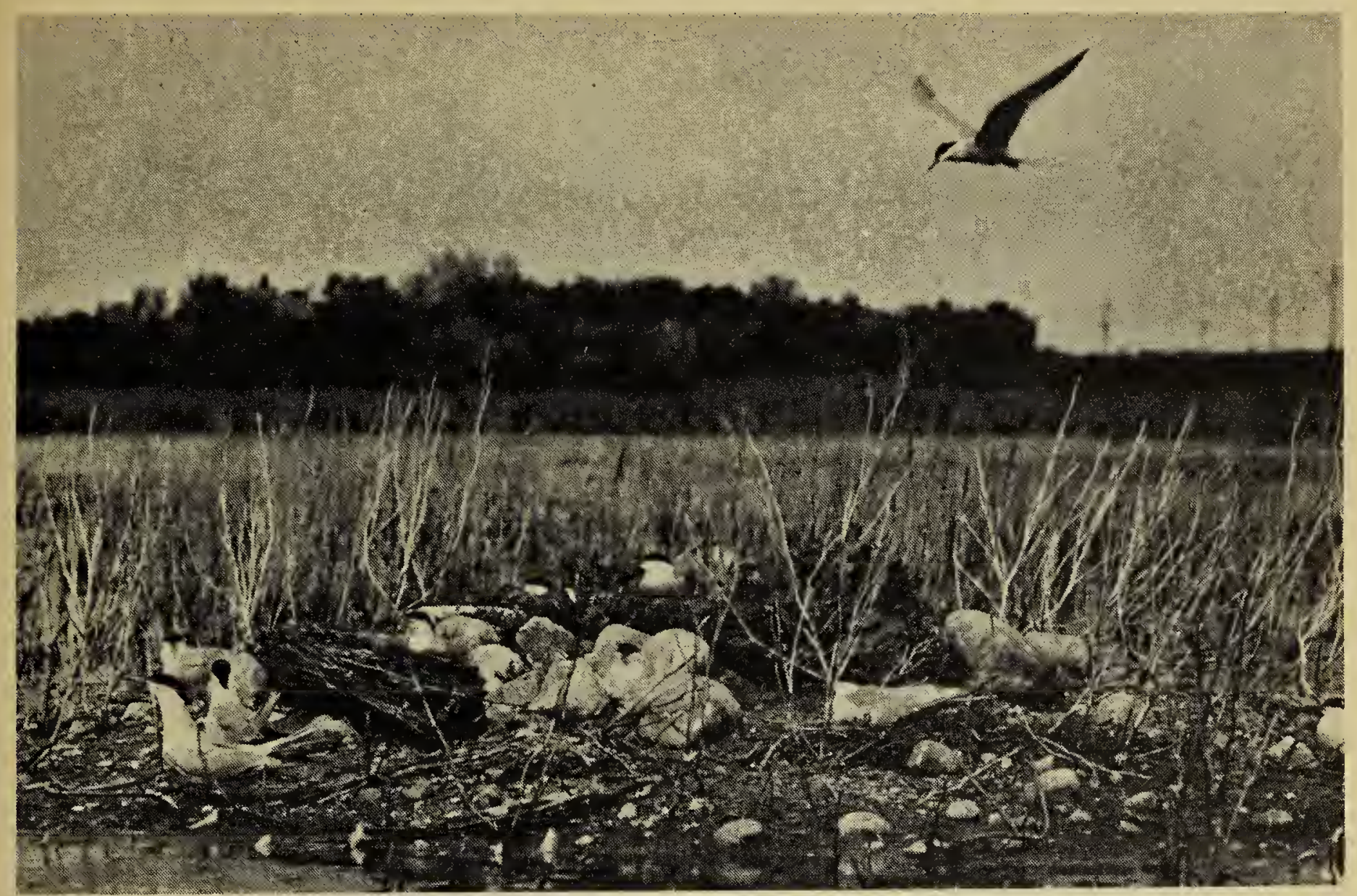

Breeding colony of Common Terns at Tern Island, 1962

Blackbirds' nests were destroyed by the 95 m.p.h. gusts of wind. The water level up tc June 23 was well above the previous year's high, the spring run-off having filled the creek. No waterfowl nests seemed to be in danger of being left high and dry before the young left, and there was ample water for all species.

The deepest water for divers was to be found in the part of the creek extending from the by-pass apprcximately a mile east. Here, where the creek's natural channel is 8 to 9 feet deep and where it is bordered by cattails and bulrushes, most of the nests were found. Large colonies of Yellow-headed Blackbirds made good use of the bulrushes, as did Canvasbacks, Redheads, Black Terns, and numerous ccots.

Owing to this year's higher water level there was a lack of mudflats and ccnsequently a noticeable decrease in the number of nesting Willets and American Avocets. "Tern Island", much favoured by Willets, Killdeer and Avccets, was under 8-10 inches of water this year.

The number of Red-winged Blackbirds found nesting was down compared with last year, pcssibly due to the lack of suitable habitat. Some were found nesting a scant two or three inches above water in dead weeds.

An area that should be given special nctice is a large growth of bulrushes and cattails lying just east of the by-pass on the south side of the creek. Here we found six species of birds living in very close proximity. Canvasbacks, Redheads, Black Terns, American Coots, Pied-billed Grebes and Yellow-headed Blackbirds were crowded together in one amazing mass. No doubt they could only coexist because of their varied feeding habits.

It shculd be mentioned that the following brief annotated list of species includes mainly those species nesting $\mathrm{cn}$ or above the water, and is not a complete account of all nesting species. For example, we ncted on two occasions, two pairs of Yellowthroats and heard them singing several times although we could not find a nest on subsequent searches. Owing to our lack of time (we were out on five different days between June 15 and June 23 and spent 45 hours in the field), we concerned ourselves mainly with those nests accessible by rcwboat and hip waders. A few nests were fcund back from the shore. 


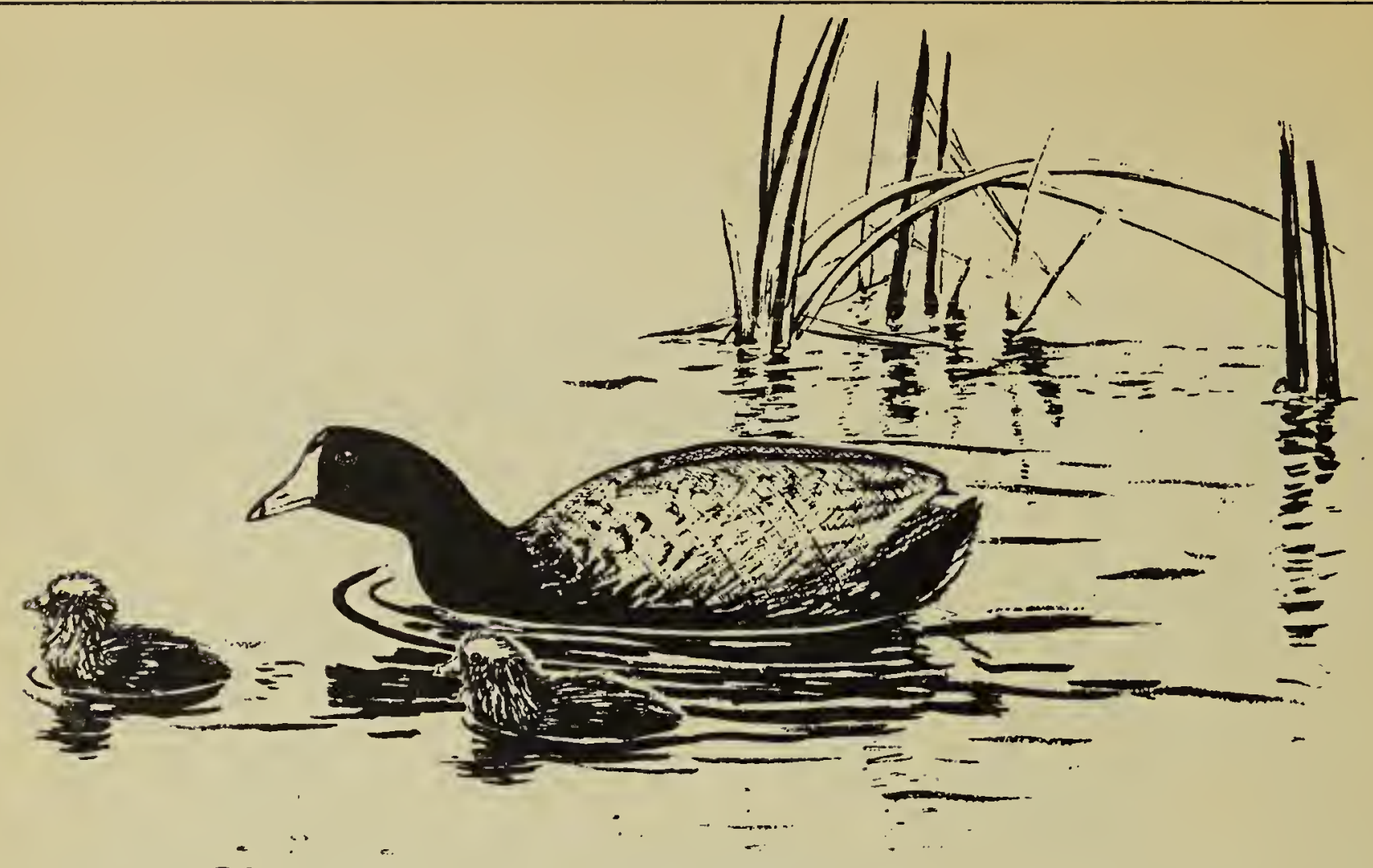

Sketch by Fred W. Lahrman Coot with young. Reprinted from BIRDS OF REGINA

ANNOTATED LIST OF SPECIES:

EARED GREBE. Podiceps caspicus. Only one nest was found along the creek, June 18, containing five eggs. A large colony, however, was located in the Waterfowl Park below the area of cur survey, studied by Fred W. Lahrman (Blue Jay, 20:158).

PIED-BILLED GREBE. Podilymbus podiceps. Common. Total of 14 nests found, one of which contained eight eggs. A nest on Tern Island contained one egg and four young, while another along the creek had three young.

CANADA GOOSE. Branta canadensis. Severai vacant nests were found out along the creek, plus five eggs floating near the southeast corner of Tern Island. By this time of the year, of course, the geese had brought off their families.

MALLARD. Anas platyrhynchos. One nest was found while dragging a field with a rcpe. Another was found on a goose nest platform on Tern Island.

REDHEAD. Aythya americana; and CANVASBACK. Aythya valisineria. Common. Total of 14 nests found. This seemed to be a bonus year for these birds, and it is the most I have ever seen here during the nesting season. It was nct uncommon to see five or six pairs of Canvasback feeding early in the morning, although the Redheads were not quite so numerous. As we discovered most of the nests while working the bulrushes we did not see the adults leave the nests, and because of the similarity of the eggs of the Redhead and the Canvasback we were forced to leave some nests unidentified. We did collect down from some of the nests which we hope can be identified. One of the nests contained 22 eggs.

RUDDY DUCK. Oxyura jamaicensis. Scarce. One nest was found cn Tern Island containing one egg, on June 23. Though several pair were seen along the creek, June 15 and June 18 , no nests were found.

AMERICAN COOT. Fulica americana. Very common. Total of 117 nests found, 16 of these being $\mathrm{cn}$ Tern Island. By June 23 hatching was fairly well advanced. Towards noon each day we would often find nests with two young just hatched and the oldest we saw was three to four days old. The largest number of eggs found in one nest was 12 , and the largest number of young seen with an adult was six. On June 18 Fleming found four young decapitated beside a nest and nearby three dead young lay by a nest.

KILLDEER. Charadrius vociferus. Common. Three nests found in grassy field during a stop for lunch. Adults always seen, thcugh we did not make much effort to locate their nests.

COMMON TERN. Sterna hirundo. 12 nests were found crowded together on a mound of gravel within an area 
of less than nine square feet. Less than a square foot for a nest and a bird. One chick hatched by June 23 . This amazing struggle for existence is quite typical of the entire waterfowl park and its related wildlife.

BLACK TERN. Childonias niger. Very common. Total of 45 nests found, two of these on Tern Island. Nests were found mainly in small colonies, one of which contained 14 nests. Some nests were ready, but not laid in, by June 18. Many birds were nesting on floating debris such as boards, etc.

YELLOW - HEADED BLACKBIRD. Xanthocephalus xanthocephalus. Very common. Total of 120 nests. Nesting in colonies everywhere. By June 23, the young from six to seven nests had already flown, and many nests had two or three young. Two nests were found built one above the other on the same bulrush stalk, each containing two eggs. On the 18th many nests were still under construction, mainly in the "wet stage".

RED-WINGED BLACKBIRD. Agelaius phoeniceus. Common, but not as common as in 1961. Total of 32 nests found. Two colonies, one with 10 nests and the other with 12 . Both colonies were built low to the water in dead weeds. By June 20, seven nests had young.

BROWN-HEADED COWBIRD. Molothrus ater. Two Red-winged Blackbirds' nests contained one cowbird egg each. Both were removed.

[Editor's Note: In spite of the accessibility and central location of the Regina Waterfowl Park its plant and animal life have had very little intensive study by naturalists. Many cpportunities are being missed-Dr. Al Hochbaum of the Delta Waterfowl Research Station, has pointed out that the large wintering population of Mallards provides a quite unique oppcrtunity for the study of Mallard behaviour. The only bird behaviour studies we know of that have been carried on at the Waterfowl Park have been studies made by Dr. Robert W. Nero of the Yellow-headed and Red-winged Blackbirds. Over the years, there have been only occasional waterfowl counts, banding projects,. and casual recording of breedings birds. Margaret Belcher's Birds of' Regina (1961), which reviews over 50 years of Regina records, gives only the most general indications of the breeding status of species at the Wascana Marsh. Hence the worth of this unpretentious study undertaken by Sanderson and Fleming. Though they spent a quite inadequate period of time at the Marsh -a total of only 45 hours-they were able to establish important facts such as the abundance of the coot (117 nests found), a common species on which Belcher could only collect the following information: "Several nests were found each year from 1950 to 1953 , with six nests in 1950 , and broods of coots seemed especially numerous cn the marsh in 1960. From 1957 to 1959 coots with young were reported only once, on July 7, 1957 (Belcher)." More and serious studies should be undertaken in this natural marsh which is being incorporated into Regina's "Wascana Centre". The appeal of the area to all city residents and visitors interested in wildlife is described in a little 19-page bulletin recently published by the Saskatchewan Museum of Natural History, "Wascana Bird Sanctuary" (Popular Series No. 6) available from the Museum for 10 cents.

\section{EARED GREBE COLONY AT REGINA, 1963}

by Fred W. Lahrman, Saskatchewan Museum of Natural History, Regina

For two years we have reported large colonies of the Eared Grebe at the Regina Waterfowl Park (Blue Jay, 19:170-171; 20:157). During the summer of 196148 nests were under observation at the marsh where no grebes had nested since the early 1950 's. In 1962 this number grew to 165 nests, an impressive increase. It is of interest that a slightly larger number of nests appeared in 1963. On May 12 the grebes were already nesting (1963 first arrival date for the Regina area-April 28), ohe colony starting up at the city power house, and one at the Broad Street Bridge. On June 8, 100 nests were counted on the east side of the park below "Faraway House", on June 16, 29 were counted at the Broad Sireet Bridge, and Walter Sweet reported 50 at the power house, a total of 179 .

These colonies were in approximately the same location as last year, except that there were no nests south of "Goose Island" where there had been a small colony of 14 in 1962 . 